\title{
Integrated Vector Management as an Effort to Anticipate the Spread of DHF in Tanjungpinang
}

\author{
Kusna Ramdani, Mursid Raharjo, Yusniar H. Darundiati
}

\author{
Environmental Health of Diponegoro University - Semarang \\ Email: kusnaramdani.kr@gmail.com
}

\begin{abstract}
DHF is a vector-borne disease caused by dengue virus transmitted to humans through the bite of the Aedes aegypti and Aedes albopictus mosquitoes. Many efforts have been taken by the government to overcome the occurrence of dengue cases. However, the cases in Tanjungpinang continue to occur throughout the year and even increased in 2018. The implementation of Aedes vector control program is still done individually. Therefore, an approach which involves all sectors, including government, the private sector, and society, is needed.
\end{abstract}

A descriptive and analytical observational study of 50 samples and 214 coordinate points of DHF patients were carried out for mapping and dynamics of transmission surveys. Out of 434 DHF patients, $60.1 \%$ of them were from the Tanjungpinang Timur sub-district with a pattern of group distribution, especially in urban villages with the highest population density namely Pinang Kencana Village. Vector surveillance showed $61.1 \%$ villages in the indices of Aedes aegypti and/or Aedes albopictus HI > 5 and $R R>0.025$.

Control of Aedes sp is not only the responsibility of the health sector but is also the responsibility of all sectors. To ensure the continuity of vector control, the development of a strategy in the form of integrated vector management is needed. The integrated vector management concept is to integrate effective and economical vector control methods involving all sectors.

Thus, in order to implement integrated vector management, commitment from stakeholders and related sectors is required. Besides, it requires the active role of the community to be involved in vector control.

Keywords- Integrated Vector Management, DHF, Tanjungpinang.

\section{INTRODUCTION}

Dengue Hemorrhagic Fever (DHF) is one of the vectorborne diseases that have spread rapidly following the geographical and regional distribution to various countries. An estimated 50 million cases of dengue occur every year. Indonesia is a country with dengue cases that occur every year. Meanwhile, Indonesia is a country with dengue cases that occur every year. The cases are almost evenly distributed throughout the region. In 2017, Incident Rate (IR) in Indonesia amounted to $22.55 \%$ with a Case Fatality Rate (CFR) of $0.75 \%$. (1) Riau Islands is a province with the second highest CFR in Indonesia with IR of $30.35 \%$ and CFR of $1.74 \%$.

This study aims to describe the implementation of integrated vector management in anticipation of the spread of DHF and to know the relationship of Aedes vector index in the form of $H I$ \& RR with the spread of DHF in Tanjungpinang. Tanjungpinang is one of the cities in the Riau Islands which has a wet tropical climate with air temperatures ranging from $27.7^{\circ} \mathrm{C}$, humidity of $81,5 \%$, and rainfall of $15.72 \mathrm{~mm}$ with the number of rainy days of 20 days per month. Conceptually, Tanjungpinang is an area with the optimum climate for breeding Aedes sp mosquitoes. Therefore, dengue cases in Tanjungpinang occur every year. Data shows a significant increase in cases from 79 patients in 2017 to 352 patients in 2018 and 80 patients in January 2019.

DHF will not occur without a vector namely Aedes sp. Vector control activities are currently only carried out by the health sector. However, a good strategy needs to be supported by all sectors in order to run optimally. Therefore, to anticipate the spread and increase in cases, an integrated vector control concept which involves all sectors including government, private sector and society are needed.

\section{METHOD}

This study is a descriptive study for the formation of integrated vector management and observational analytic with a cross-sectional approach to determine the relationship of House Index (HI) and Resting Rate (RR) with the spread of DHF in Tanjungpinang. The population in this study was 434 DHF patients who suffered from DHF in 2018 and January 2019 in Tanjungpinang. The sampling was done using purposive technique sampling. The number of the samples for interviews was calculated using the following formula:

$$
\frac{N Z^{2} P(1-P)}{N d^{2}+Z^{2} P(1-P)}
$$


The calculation shows a number of samples 44.01 were needed for this study. However, to anticipate the dropout, $10 \%$ was added. Thus, 48.41 rounded up to 50 samples were involved in this study with the criteria of suffering from dengue in October - December 2018 and January 2019. In addition to mapping and describing the dynamics of distribution, coordinates of $214 \mathrm{DHF}$ patients were measured.

\section{RESULTS}

Tanjungpinang is a medium city with a population of 271,645 people with a growth rate of $1.13 \%$. The spread of population is still uneven with $42.13 \%$ of the population in the Tanjungpinang Timur Sub-District. The forming soil layer is hard and difficult to absorb water. Therefore, Tanjungpinang has a problem with clean water supplies which causes people to have a habit of sorting water on drums, buckets, and others .

Table 1. Distribution of DHF in 2018 and January 2019, HI, RR, Temperature, Humidity, \& Wind Speed of Urban Village in Tanjungpinang.

\begin{tabular}{|c|c|c|c|c|c|c|c|}
\hline No & Village & $\begin{array}{c}\text { DHF } \\
\text { Patients }\end{array}$ & $\mathrm{HI}(\%)$ & $\mathrm{RR}$ & $\begin{array}{c}\text { Temperature } \\
\left({ }^{0} \mathrm{C}\right)\end{array}$ & $\begin{array}{c}\text { Humidity } \\
(\%)\end{array}$ & $\begin{array}{l}\text { Wind } \\
\text { Speed } \\
(\mathrm{mps})\end{array}$ \\
\hline & Tanjungpinang & & & & & & \\
\hline 1 & Timur & 27 & 7.50 & 0.06 & 29.2 & 78 & 3 \\
\hline 2 & Dompak & 1 & 0.00 & 0.00 & 29.3 & 78 & 1 \\
\hline 3 & Sei Jang & 21 & 22.50 & 0.38 & 27.0 & 93 & 2 \\
\hline 4 & Tanjung Ayun Sakti & 22 & 12.50 & 0.06 & 28.0 & 86 & 2 \\
\hline 5 & Tanjung Unggat & 19 & 17.50 & 0.19 & 27.8 & 80 & 2 \\
\hline 6 & Air Raja & 27 & 20.00 & 0.00 & 28.0 & 82 & 4 \\
\hline 7 & Pinang Kencana & 112 & 21.04 & 0.34 & 28.2 & 78 & 3 \\
\hline 8 & Kampung Bulang & 14 & 2.50 & 0.06 & 27.4 & 80 & 4 \\
\hline 9 & Melayu Kota Piring & 42 & 24.32 & 0.38 & 27.8 & 78 & 2 \\
\hline 10 & Batu Sembilan & 66 & 17.64 & 0.17 & 27.4 & 81 & 3 \\
\hline 11 & Bukit Cermin & 8 & 2.50 & 0.00 & 28.2 & 78 & 3 \\
\hline 12 & Kamboja & 4 & 0.00 & 0.00 & 27.4 & 80 & 4 \\
\hline \multirow[t]{2}{*}{13} & Kampung Baru & 10 & 4.00 & 0.13 & 27.8 & 78 & 2 \\
\hline & Tanjungpinang & & & & & & \\
\hline 14 & Barat & 31 & 10.00 & 0.13 & 27.4 & 81 & 3 \\
\hline 15 & Senggarang & 2 & 0.00 & 0.00 & 25.7 & 92 & 3 \\
\hline 16 & Tanjungpinang Kota & 6 & 3.23 & 0.00 & 27.6 & 82 & 4 \\
\hline 17 & Kampung Bugis & 21 & 20.00 & 0.31 & 27.3 & 80 & 3 \\
\hline \multirow[t]{2}{*}{18} & Penyengat & 1 & 0.00 & 0.00 & 27.0 & 82 & 2 \\
\hline & Total/ Average & 434 & & & 27.7 & 81.5 & 2.8 \\
\hline
\end{tabular}

1. Mapping of Areas with Cases

Incidence Rate of DHF cases in 2018 in Tanjungpinang amounted to 130.32 per 100,000 populations which spread in seventeen villages. The three villages with the highest DHF cases were the Pinang Kencana Village with
95 cases, Batu 10 Village with 60 cases and Melayu Kota Piring Village with 33 cases. Those three villages are located in the Tanjungpinang Timur sub-district. 


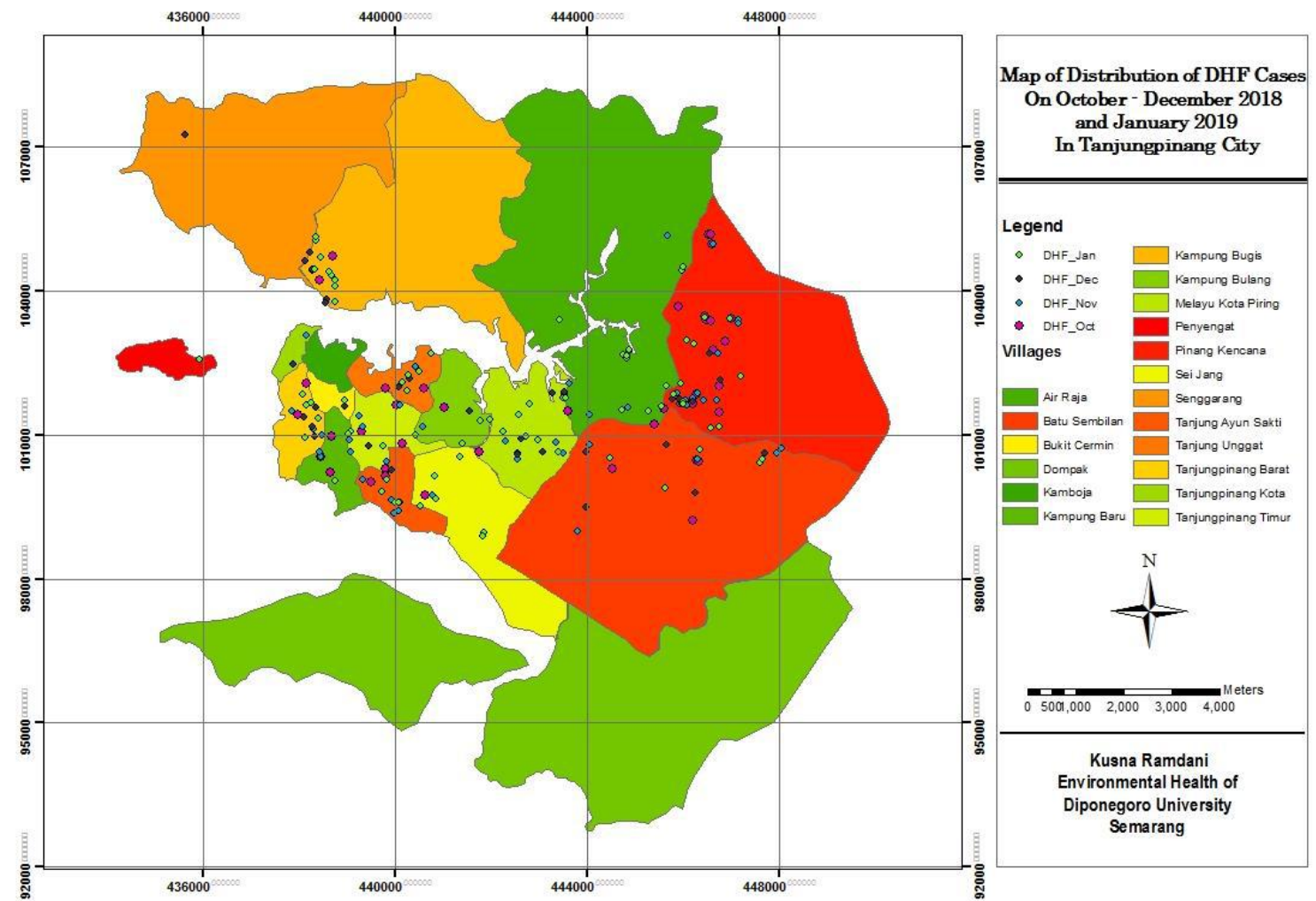

Fig.1: Distribution of DHF Patients in Tanjungpinang in October - December 2018 and January 2019

\section{Dynamic Transmission of DHF}

The survey of dynamic transmission was carried out on DHF patients in October, November, December 2018 and January 2019.

Table 2. Average Nearest Neighbor (ANN) Summary Calculation Results.

\begin{tabular}{ll}
\hline Average Nearest Neighbor (ANN) Summary \\
\hline Observed Mean Distance & 708,374 \\
Nearest Neighbor Ratio & 0,186 \\
Z-Score & $-22,781$ \\
p-value & 0,000 \\
\hline
\end{tabular}

Based on the spatial statistical analysis of the Average Nearest Neighbor (ANN) using ArcGIS software, the results of the Nearest Neighbor Ratio $(\mathrm{NNR})=0.186<1$. It means the pattern of dengue incidence in Tanjungpinang was clustered especially in urban villages with the highest population density namely Pinang Kencana Village. ANN calculations also produced an average distance between cases of 708,374 meters.

Table 2 presents the results of the bivariate analys is with the spread of DHF cases in Tanjungpinang.
Table.3: Results of Chi-Square output between HI and RR with DHF Spreading Pattern

\begin{tabular}{cccc}
\hline & $P$-value & OR & CI 95 \% (lower-upper) \\
\hline $\begin{array}{c}\text { House } \\
\text { index }(\mathrm{HI})\end{array}$ & 0,637 & 2,5 & $0,370-16,888$ \\
$\begin{array}{c}\text { Resting } \\
\text { Rate }(\mathrm{RR})\end{array}$ & 0,05 & 16 & $1,315-194,623$ \\
\hline
\end{tabular}

The result of HI p-value analysis in Chi-Square is $0,637>0,05$. It means there is no relationship between $\mathrm{HI}$ and the pattern of DHF spread. Meanwhile, RR p-value is $0.05 \leq 0.05$ which means there is a relationship between $\mathrm{HI}$ and the spreading pattern of DHF in Tanjungpinang. In conclution, RR becomes a risk factor for dengue spread in Tanjungpinang.

\section{Vector Density}

In order to find out the existence of DHF vectors, a survey on the life of larva and Aedes sp mosquitoes was conducted. The survey was conducted with a purposive sampling technique on 50 DHF patients in October, November, December 2018 and January 2019. Larvae were found in drums holding water, used tires, fences made of bamboo, and glasses of mineral water. In addition, Aedes sp mosquitos breeding sites were also found in schools. 
The survey found that both larval and adults stages of Aedes $s p$ vectors were shown in $61.1 \%$ Aedes $s p$ index, $\mathrm{HI}>5 \%$ and Resting Rate (RR) above 0.025 . Villages with the Aedes $s p$ index met the requirements set by the Minister of Health Regulation No. 50 of 2017 were Dompak, Kampung Bulang, Bukit Cermin, Kamboja, Kampung Baru, Senggarang and Penyengat Villages.

\section{Joint Movement to Fight Aedes Larvae}

Socialization was carried out by conveying the causes, transmission, and control methods for Aedes sp mosquitoes at the recitation and social gathering programs. In addition, the socialization was officially held on January 29, 2019, at Aston Hotel with speakers from Port Health Office (KKP) Class II of Tanjungpinang and national resource person who is an expert of MVT, an academic from Universitas Diponegoro, Semarang. The socialization aims to increase knowledge and arouse the commitment of every party to play an active role in controlling the vectors of Aedes $s p$. The socialization was opened by the Head of the Riau Islands Provincial Health Board and was attended by all stakeholders in the port as well as the local government of Tanjungpinang. After the socialization was carried out, the health and non-health sectors coordinated to move together to eradicate Aedes sp.

The joint movement to eradicate Aedes was a city-level movement initiated by the Board of National Family Planning and Population Control in order to include all sectors, both government and the community, to jointly fight dengue by eliminating Aedes $s p$ mosquito breeding sites in houses and offices. This joint movement carried out on 16 February 2019 was opened by the Deputy Mayor of Tanjungpinang. That event was attended by the chairman of commission 1 Regional Assembly (DPRD) Tanjungpinang in charge of health, Head of $P P \& P L$ Riau Islands Provincial Health Board, Family Planning Health and Population Control Board, Board of Education, Board of Communication and Information, Board of Transportation, Board of Public Works, Tanjungpinang Timur Sub-District, Pinang Kencana Village, Class II KKP Tanjungpinang, Health of Polytechnic, Navy Health Service, Indonesian Red Cross, Saka Bakti Husada Scout, Baru IX Health Center, Melayu Kota Piring Health Center, Mekar Baru Health Center, College of Health Science HangTuah, Association of Indonesian Public Health Experts (IAKMI) Tanjungpinang, Association of Indonesian Public Health Scholars (Persakmi) Tanjungpinang, Pinang Kencana housing community 1, 2, 3 , and Community Police Officer of Tanjungpinang Timur Sector Police.

With the theme "Let's Eradicate! No Aedes larvae, No DHF," the activity was held in the Pinang Kencana Sub-
District of Tanjungpinang Timur because $60.1 \%$ of DHF cases occurred in the sub-district. The joint movement was expected to arouse the enthusiasm of all parties especially the community in order to play an active role in eradicating mosquito nests and to give example to other regions that joint movement will succeed in reducing and preventing dengue cases.

\section{DISCUSSION}

Tanjungpinang is a city located on an archipelago with a layer of soil in the form of hard bauxite and difficult to absorb water. Therefore, even though Tanjungpinang has quite high rainfall, the supply of clean water in this area is still a problem which has not been completely solved. Thus, in order to meet the need for clean water, the community has a habit of storing water in drums, buckets, and others.

DHF cases are closely related to temperature, humidity, rainfall, and the existence of breeding sites of Aedes $s p$ mosquitoes as the main vector. Aedes $s p$ mosquitoes as the main vector which has the habit of laying eggs on the water reservoirs that do not directly ground. The life cycle of Aedes sp mosquito takes place within 9-12 days with the habit of looking for human or animal blood in the morning and evening for the maturation process of the eggs. (2)(3)(4)

At first, the main strategy of DHF control was to eradicate adult mosquitoes through fogging. Moreover, the community was already aware that DHF control can be done by fumigation. There is a saying that if fumigation or fogging has not been carried out, there has been no action. However, this strategy poses a risk. Continued use of insecticides over a long period of time will make mosquito resistance to insecticides. Thus, the strategy is expanded by the use of larvacides against mosquitoes at the larval stage. However, the above-mentioned strategies currently are not able to reduce IR because dengue cases still occur throughout the year and even increase in numbers of areas affected by DHF. Then, there is a strategy in the form of the Eradication of Mosquito Nest (PSN) through $3 \mathrm{M}$ plus. $3 \mathrm{M}$ plus consists of cover, clean, and recycle places that could be the breeding grounds for the Aedes mosquitos. Vector control activities in the context of anticipating DHF are currently still handed over to the health sector. Although the government makes a very good strategy, if it is not supported by all sectors, the control will not run optimally.

The results of spatial statistical analys is obtained Nearest Neighbor Ratio $(\mathrm{NRR})=0.186<1$. It means that the pattern of dengue incidence in Tanjungpinang is clustered especially in urban villages with the highest population density namely Pinang Kencana Village. Kedung Mundu 
Semarang. This finding is in line with a study conducted by Kedung Mundu Semarang Health Center on the pattern of DHF spread. ${ }^{(5)}$

Aedes $s p$ vector survey results obtained $61.1 \%$ of the village Aedes $s p$ index $\mathrm{HI}>5 \%$ and Resting Rate (RR) above 0.025 . This shows that there are still many villages with the Aedes $s p$ index that do not meet the requirements as stated in Minister of Health Regulation No. 50 of 2017 concerning Environmental Health Quality Standards and Health Requirements for Vector and Animals and Control which requires the index of Aedes aegypti and/or Aedes albopictus for ABJ larvae to be $\geq 95$ or $H I<5$ and for adult stage $R R \leq 0.025$. ${ }^{(6)}$ This finding is consistent with the finding of another study conducted in 2016 which stated that the highest distribution of DHF patients in Tanjungpinang was Tanjungpinang Timur Sub-District. (7) The results of bivariate analysis in Chi-Square between $\mathrm{HI}$ and the spread of dengue incidence in Tanjungpinang showed that there is no significant relationship because $\mathrm{p}$ value wa $0,637>0,05$. Meanwhile, there is a significant relationship between $\mathrm{RR}$ and the spread of dengue incidence in Tanjungpinang indicated by $\mathrm{p}$-value $\leq 0.05$. Likewise, with $95 \%$ CI lower-upper above 1 which means $\mathrm{RR}$ are risk factors for dengue spread. In January 2019, there were still increasing cases in the same village. Moreover, new patients were also found from a village where there were no cases before. The findings of other studies stated that the high density and population of Aedes aegypti caused the faster transmission of DHF and the risk of dengue fever. ${ }^{(8)(9)(10)(11)(12)}$

Currently, vector control is carried out by the fumigation method in the dwelling place of DHF patients and their surroundings after getting the results of epidemiological investigations. The fumigation is mostly carried out in 1 cycle only. Ideally, vector control is carried out periodically in both larvae and adult states by always carrying out vector surveillance either there is a case or not. The control should be done by fumigation with 2 cycles at a 1-week interval. The control should be done without waiting for the occurrence of the case. According to a study by Dian Perwitasari et al., there is also a need for a combination of vector control through fumigation with the use of repellents in individuals in order to reduce the DHF IR. (13)

$51.7 \%$ DHF cases in Tanjungpinang occur at the age of 5 to 14 years old which is the school-age period from kindergarten to high school. This is supported by the results of vector surveillance in schools found breeding grounds for Aedes $s p$ mosquitoes in the bathtub, used mineral water glass, and a fence made of bamboo with the upper part capable of sorting water. This is in accordance with the results of a study conducted in Kupang that the highest incidence of dengue was at the age of 5-9 years.
(14) Thus, the active role of the board of education is needed in providing understanding to students and the school to maintain the school environment in order to be free from the breeding grounds of Aedes $s p$ mosquitoes through Jumat Bersih (Friday, Clean Day) and incorporate them into the school curriculum. In accordance with a study conducted by Mursid Rahajo, malaria lessons need to be included in the elementary school education curriculum as one of the elements of integrated vector management in order to cope with the incidence of malaria in Purworejo District, Jawa Tengah. (15)(16)

Previous studies show that the community participation in DHF control is still lacking due to lack of awareness and care of the community in the surrounding environment. The community feels the urge to control larvae if there is an order from the prominent figure to work together, there is a joint movement initiated by the board of health, or there are many cases of dengue in the area. Moreover, many people do not want to accept the arrival of the vector surveillance team to inspect the reservoir of water in their home.

In addition, the implementation of vector surveillance from the government which tasks are given to jumantik cadres in one urban village is on average 2 people. Sometimes, jumantik only becomes a side job because of a modest salary. Therefore, jumantik is not enough to handle all urban areas with a broad target. Thus, jumantik cadres are often found to do surveillance when people already suffer from dengue.

Vector surveillance is ideally carried out by an independent team specifically tasked with handling Aedes vector with honorariums in accordance with the minimum wage in order for the staffs to work optimally. For example, Semarang Government has established a health surveillance staff (gasurkes) stationed in each village coordinated by the coordinator at the sub-district level. Before Gasurkes was formed in 2014, Semarang ranked first as the city with the highest DHF in Jawa Tengan Province. In 2015, Gasurkes was in action and made Semarang ranked third in 2016. In 2017, the cases dropped to 299 cases and in 2018 the cases decline from 299 to 72 cases. It made Semarang ranked 25-29 from 35 cities/regencies in Jawa Tengah Province. It means that Semarang had succeeded in handling DHF.

Tanjungpinang is a city located in the Riau Islands region where transportation facilities for people to go to Tanjungpinang are sea transportation in the form of ferries, roro, cargo ships, speedboats, canoes, and aircraft. Therefore, Tanjungpinang has several exits and entry areas in the form of ports and airports which increase the risk factor for the occurrence of DHF through the traffic of people and transportation equipment.(17) Health 
problems in the port area and the airport are delegated to Tanjungpinang Class II KKP. One of the routine activities carried out by Tanjungpinang Class II KKP is Aedes sp vector control through periodic larvae observation, adult mosquito surveys, and larvae and mosquito eradication through larvasidation and fumigation in the perimeter as well as buffer ports areas and airport. Mosquito control at larval and adult stages are carried out if $\mathrm{HI}>1$ because internal regulations require that there is no vector in the perimeter area of the international port and airport.

Aedes $s p$ vector control in the administrative area of Tanjungpinang was carried out by the Board of Health based on the occurrence of DHF cases and the findings of epidemiological investigations conducted by the health center. There were differences in the control systems carried out by the KKP with the Board of Health. The lack of synergy of vector control carried out between health and non-health sectors as well as the lack of awareness and active participation of the community has increasingly increased the spread of dengue cases in Tanjungpinang. According to a study conducted by Wiwik Trapsilowati et al., the importance of the active role of the community tackling the incidence of DHF. In addition, Ismet Sawir in his study stated the importance of the role of the community in preventing mosquito-borne disease while the government is only a facilitator. (18)(19) (20) (21)

Taking into account the conditions in Tanjungpinang, it is necessary to develop an integrated vector management concept which involves all sectors including government, the private sector, and society. In order to implement integrated vocational management, commitment from stakeholders and related sectors is needed. Aedes vector control is the main vector of DHF. (22) (23) (24) (25) (26)

\section{CONCLUSION}

Three villages with the highest dengue cases in Tanjungpinang are Pinang Kencana, Batu 10, and Melayu Kota Piring Villages. Those three villages are part of Tanjungpinang Timur Sub-District.

The survey of dynamic transmission was carried out on DHF cases that occurred in October, November, December 2018 and January 2019 with the $\mathrm{N}$ ratio 0.186 . It means the pattern of dengue spread in groups with an average distance between patients of 708.374 meters. The survey of vector feeding was carried out on Aedes sp mosquitoes in larva/larvae produced by 10 villages with $\mathrm{HI}$ above 5\% and Aedes sp mosquitoes at the adult stage 11 villages with RR above 0.025 . Furthermore, Chisquare analysis showed that there was a relationship between $\mathrm{HI}$ and RR with the pattern of DHF spread in Tanjungpinang.
The control of Aedes $s p$ is not only the responsibility of the health sector but also the responsibility of all sectors in order to ensure the continuity of vector control. It is necessary to develop an integrated vector management strategy. The integrated vector management concept is to integrate effective and economical vector control methods involving all sectors to suppress vector populations. Thus, their presence is not at risk of transmitting disease. In order to implement integrated vector management, commitment from stakeholders and related sectors is required. Besides, it requires an active role of the community to be involved in vector control.

Socialization was carried out through community gathering such as recitation and socialization in Aston hotel. The socialization then was followed by coordination between the health and non-health sectors in order to form a joint movement to eradicate Aedes sp. centered in Pinang Kencana village involving all sectors and communities. The joint movement was opened by the Deputy Mayor of Tanjungpinang.

\section{ACKNOWLEDGMENTS}

The authors would like to expresses our gratitude to the head of the Board of Human Resources Development and Empowerment of the Ministry of Health as the party that funded this study. The authors would also like to acknowledge the Board of Health, Population and Family Planning Management of Tanjungpinang and the Port Health Office Class II of Tanjungpinang for assistance and help during the study.

\section{REFERENCES}

[1] Data dan informasi profil kesehatan Indonesia 2017. Kemenkes RI, Jakarta;

[2] Roziqin A, Hasdiyanti F. Pemetaan daerah rawan penyakit Demam Berdarah Dengue (DBD) Di Pulau Batam. J Integr. 2017;9(2):106-12.

[3] Wirayoga MA. Hubungan kejadian Demam Berdarah Dengue dengan iklim di Kota Semarang Tahun 2006-2011. Unnes J Public Heal. 2016;1(1):1-8.

[4] Masrizal, Sari NP. Analis is kasus dbd berdasarkan unsur iklim dan kepadatan penduduk melalui pendekatan gis di tanah datar. J Kes Mas Andalas. 2016;166-71.

[5] Kusuma AP, Sukendra DM. Unnes Journal of Public Health. Unnes J Public Heal. 2016;5(1).

[6] Peraturan Menteri Kesehatan RI Nomor 50 Tahun 2017. Jakarta: Kementerian Kesehatan RI; 2017.

[7] Arifin NF, Adi MS, Suhartono, Martini, Suwondo A. Analisis spasial dan temporal demam berdarah dengue di Kota Tanjungpinang tahun 2016. Semarang; 2016. Report No.: 61460. 
[8] Yudhastuti R, Vidiyani A. Hubungan kondisi lingkungan, kontainer, dan prilaku masyarakat dengan keberadaan jentik nyamuk Aedes aegypti di daerah endemis demam berdarah dengue Surabaya. J Kesehat Lingkung. 1(no 2):170-83.

[9] Rivyantanti RD, Arifin NF, Raharjo M, Darundianti YH. Application of spatial analysis of dengue hemorrhagic fever risk factors in Taman District Madiun. J Visikes J Kesehat Masy. 2016;(2).

[10] Sari IP, Nofita E. Hubungan kepadatan larva Aedes spp . dengan Kejadian Demam Berdarah Dengue di Kelurahan Lubuk Buaya Kecamatan Koto Tangah Kota Padang. J FK Unand. 2017;6(1):41-8.

[11] Sucipto PT, Raharjo M. Faktor - faktor yang mempengaruhi kejadian penyakit Demam Berdarah Dengue (DBD) dan jenis serotipe virus Dengue Di Kabupaten Semarang. J Kesehat Lingkung Indones. 2015;14(2):51-6.

[12] Farahiyah M, Nurjazuli, Setiani O. Analisis spasial faktor lingkungan dan kejadian DBD di Kota Demak. Buletin Peneilitian Kesehatan. 2014;42(1):25-36.

[13] Perwitasari D, Munif A, Supriatna AA. Model intervensi pengendalian DBD untuk menurunkan IR berdasarkan kombinasi fogging dan repelen di Kabupaten Sintang Kalimantan Barat. J Ekol Kesehat. 2013;12:57-71.

[14] Maran AA, Nurjazuli, Suhartono. Studi deskriptif kejadian Demam Berdarah Dengue (DBD) dengan pendekatan spasial di Kota Kupang (Analisis Data sekunder Tahun 2010-2011). J Kesehat Lingkung Indones. 2012;11(2).

[15] Mursid Raharjo. Malaria content in elementary school curriculum in supporting integrated vector management for the elimination of malaria in Purworejo district. Int $\mathrm{J}$ english Lit Soc Sci. 2019;(1):193-7.

[16] Siyam N, Cahyati WH. Penerapan School Based Vector Control (SBVC) untuk pencegahan dan pengendalian vektor penyakit di sekolah. J MKMI. 2018; $14: 86-92$.

[17] Wilder-Smith A. Dengue infections in travellers. J Challenges Infect Dis. 2013;301-11.

[18] Trapsilowati W, Pujiyanti A, Irawan AS. Pengembangan model pengendalian vektor demam berdarah dengue berbasis masyarakat. Salatiga; 2011.

[19] Sawir I. Kesehatan lingkungan dan epidemiologi: pembentukan, pembinaan dan pemberdayaan kelembagaan sebagai unsur strategi terpadu pengendalian populasi nyamuk 1. In: Kesehatan Lingkungan. Pondok Cabe: FMIPA Universitas Terbuka; 2011.
[20] Trapsilowati W, Mardihusodo SJ, Prabandari YSu, Mardikanto T. Partisipasi masyarakat dalam pengendalian vektor demam berdarah dengue di kota semarang provinsi jawa tengah. J Vektora. 2017;7(September 2015):15-22.

[21] Sukesi TW, Supriyati, Satoto TBT, Wijayanti MA, Padmawati RS. Pemberdayaan masyarakat dalam pengendalian Demam Berdarah Dengue. J Vektor Penyakit. 2018;12:67-76.

[22] Berg $H$ Van Den, Takken W. Evaluation of integrated vector management. J Trends Parasitol. 2008;25(Dece mber):71-6.

[23] Raharjo M, Hanani Y, Ginanjar P. The effectiveness of integrated vector management ( IVM ) in eliminating malaria in Indonesia: A case study in the Purworejo District, Central Java Province, Indonesia. J KnE Life Sci. 2018;2018:1-8.

[24] Berg H Van Den, Takken W. Integrated vector management ( IVM ): from concept to practice. Malar J. 2010;9(Suppl 2):2010.

[25] Bos R. WHO global strategic framework for integrated vector management. In Genewa: Public Health and Environment, WHO; p. 1-20.

[26] WHO. Handbook for integrated vector management. France: WHO library cataloguing in publication data; 2012. 